\title{
TERAPI KOGNITIF PERILAKU DALAM KELOMPOK UNTUK KECEMASAN SOSIAL PADA REMAJA PUTRI DENGAN OBESITAS
}

\section{COGNITIVE BEHAVIORAL THERAPY IN GROUP FOR SOCIAL ANXIETY IN FEMALE ADOLESCENT WITH OBESITY}

\author{
Dera Andhika Duana \\ M. Noor Rochman Hadjam \\ Fakultas Psikologi Universitas Gadjah Mada Yogyakarta \\ E-mail: dera_pooh@yahoo.co.id/noor_rochman_h@yahoo.com
}

\begin{abstract}
The main purpose of this research was to know whether there was a difference in decreasing a social anxiety in the female adolescent with obesity in an experimental group and control group after given a CBT in Group. This research involved 10 female adolescent who were experiencing obesity with a Body Mass Index (IMT) minimum of 25 who were randomly would be divided into a control group and experimental group. A research design used the untreated control group design with dependent pre-test and post-test samples. A social anxiety measurement using a parameter namely diary checklist based on Nevid's et al (2003) social anxiety characteristics. The experimental group would be given a CBT in Group intervention conducted twice a week during four weeks. Data in this research was analyzed cumulatively using a Wilcoxon test methods among pre-test, post-test and follow-up results with SPSS for Windows, and also qualitative using a descriptive analysis. The result was a social anxiety in the female adolescent with obesity in an experimental group decreased after given CBT in Group compared with a control group.
\end{abstract}

Keyword: Social anxiety, CBT in group 


\section{ABSTRAK}

Tujuan utama penelitian ini adalah untuk mengetahui apakah terdapat perbedaan penurunan kecemasan sosial pada remaja putri dengan obesitas pada kelompok eksperimen dan kontrol setelah diberikan Terapi Kognitif Perilaku dalam Kelompok. Penelitian ini melibatkan 10 orang remaja putri yang mengalami obesitas dengan IMT minimal 25 yang secara random akan dibagi menjadi kelompok kontrol dan kelompok eksperimen. Desain penelitian yang digunakan adalah the untreated control group design with dependent pre-test and post-test samples. Pengukuran kecemasan sosial menggunakan alat ukur kecemasan sosial berupa diary checklist berdasarkan karakteristik kecemasan sosial Nevid, dkk (2003). Kelompok eksperimen akan diberikan intervensi Terapi Kognitif Perilaku dalam Kelompok yang dilakukan dua kali seminggu selama empat minggu. Data dalam penelitian ini dianalisis secara kuantitatif menggunakan metode uji Wilcoxon antara hasil pre-test, pascates, dan tindak lanjut. dengan SPSS for windows, serta secara kualitatif dengan menggunakan analisis deskriptif. Hasil penelitian adalah kecemasan sosial pada remaja putri yang mengalami obesitas pada kelompok eksperimen mengalami penurunan setelah diberi Terapi Kognitif Perilaku dalam Kelompok dibanding kelompok kontrol.

Kata Kunci: Kecemasan sosial, Terapi kognitif dan perilaku dalam kelompok

Obesitas merupakan fenomena yang berkembang setiap tahunnya. Hal ini dapat dikarenakan perkembangan teknologi dan pola hidup seseorang. Obesitas pada remaja cenderung buruk dibandingkan obesitas pada dewasa (Crister dalam Barlow \& Durand, 2006), yaitu angka obesitasnya meningkat tiga kali lipat selama 25 tahun terakhir, dari $5 \%$ menjadi $15 \%$ untuk remaja berumur 12-19 tahun (Crister dalam Barlow \& Durand, 2006).

Prevalensi kegemukan pada anak 16-18 tahun secara nasional masih kecil, yaitu 1,4 persen.Terdapat 11 provinsi yang memiliki prevalensi kegemukan pada remaja 16-18 tahun di atas prevalensi nasional, yaitu Kepulauan Bangka Belitung, Kepulauan Riau, DKI Jakarta, Jawa Barat, DI Yogyakarta, Jawa
Timur, Kalimantan Selatan, Sulawesi Utara, Gorontalo, Papua Barat, dan Papua. Namun demikian, prevalensi kegemukan pada remaja 16-18 tahun di semua provinsi masih di bawah 5,0\%. Prevalensi kegemukan relatif lebih tinggi pada remaja perempuan dibanding dengan remaja lakilaki. Terlihat kecenderungan meningkatnya prevalensi kegemukan pada remaja 16-18 tahun yang meningkat bersamaan dengan meningkatnya pendidikan kepala rumah tangga (Riskesdas, 2007).

Pengukuran obesitas umumnya dilakukan dengan menggunakan ukuran Indeks Massa Tubuh (IMT) yang dihitung sebagai berat badan (dalam kilogram) dibagi tinggi badan (dalam meter) kuadrat atau kilogram/meter ${ }^{2}$. Kategori berat badan berdasarkan IMT pada penduduk Asia menurut Humanhealth (Sukamto, 2005): 
Tabel 1. Kategori Berat Badan Berdasarkan IMT Pada Penduduk Asia

\begin{tabular}{lll}
\hline IMT & Kategori Berat Badan & Risiko Penyakit Penyerta \\
\hline$<18,5$ & Kekurangan berat badan & $\begin{array}{l}\text { Rendah (tetapi risiko terhadap } \\
\text { masalah klinis meningkat) }\end{array}$ \\
$18.5-22,9$ & Berat badan normal (ideal) & Rata-rata \\
$23-24,9$ & Kelebihan berat badan (overweight) & Mulai berisiko \\
$25-29,9$ & Obesitas tingkat 1 & Risiko sedang \\
$30-39,9$ & Obesitas tingkat 2 & Risiko berbahaya \\
$\geq 40,0$ & Obesitas tingkat 3 & Sangat berbahaya \\
\hline
\end{tabular}

Sarafino (1998) juga menyatakan bahwa obesitas adalah sebagai suatu simpanan yang berlebihan dalam bentuk lemak yang berdampak buruk bagi kesehatan. Obesitas banyak terjadi pada remaja awal terutama remaja perempuan karena pada saat ini terjadi peningkatan hormon estrogen dan progesteron yang menyebabkan perkembangan dari sel lemak dan penyimpanan lemak tubuh (Hoffman, Paris, \& Hall, 1994). Setelah pubertas, gadis remaja mengalami pertambahan berat badan terutama di dalam jaringan lemak, sementara remaja laki-laki mengembangkan otot dan jaringan tak berlemak (Barlow \& Durand, 2006).

Obesitas atau kegemukan merupakan suatu masalah yang ditakuti oleh para remaja. Pada lingkungan yang menghargai badan kurus, remaja dengan berat badan berlebih seringkali secara subjektif dibedakan, diejek, dan menjadi korban (Stang, 2005). Konsekuensi psikososial yang mungkin terjadi antara lain citra raga negatif yang berlangsung lama dan rendahnya harga diri, depresi atau dysthimia, isolasi dan kesepian, perasaan ditolak, kecemasan, eksternal locus of control, terikat dengan perilaku yang beresiko tinggi seperti penggunaan rokok dan alkohol atau hubungan seksual dini, tingkat kemiskinan yang lebih tinggi, dan tingkat pernikahan yang rendah pada wanita (Stang, 2005).

Bagi remaja awal, khususnya perempuan, penampilan fisik merupakan hal yang sangat penting karena pada masa ini individu mulai banyak berinteraksi (Citra \& Retnaningsih, 2009). Menurut Santrock (2003), remaja disibukkan dengan tubuh mereka dan mengembangkan citra individual mengenai gambaran tubuh mereka. Monks, Knoers, dan Haditono (2003) menjelaskan bahwa remaja mempunyai perhatian yang sangat besar terhadap penampilan dirinya. Apabila ada bagian tubuh atau seluruh tubuh yang dinilai tidak baik atau tidak sesuai dengan gambaran tubuh ideal oleh remaja, maka cenderung akan mempunyai proses sosialisasi remaja (Monks dkk., 2003). 
Menurut Barlow dan Durand (2006), salah satu faktor yang menyebabkan kecemasan adalah faktor sosial. Demikian pula menurut Astuti (2005), remaja putri yang mengalami obesitas ternyata memiliki kecenderungan mengalami hambatan dalam melakukan penyesuaian sosial. Remaja putri yang mengalami obesitas memiliki konsep diri yang negatif terhadap dirinya. Dalam situasi sosial, penderita obesitas yang mengalami kecemasan sosial memonitor situasi yang mengancam, seperti celaan maupun penolakan dan selalu merasa diawasi oleh orang lain, sehingga berusaha menghindari situasi sosial yang lebih jauh (Avants, Margolin, Kosten, \& Rounsaville, 1998). Hal inilah yang dapat membuat remaja putri dengan obesitas mengalami social anxiety yang selanjutnya akan disebut sebagai kecemasan sosial.

Menurut Gillis dkk dan Osman dkk (Gretarsdottir, Woodruff-Borden, Meeks, \& Depp, 2004), remaja perempuan memiliki prevalensi kecemasan sosial lebih tinggi dari pada remaja laki-laki. Hal ini disebabkan mereka merasa tidak percaya diri dengan obesitas yang dialaminya dan merasa dirinya tidak menarik secara fisik. Menurut Blumenthal, Leen-Feldner, Babson, Gahr, Trainor, dan Frala (2011), masa pubertas memiliki kerentanan mengalami simtomatologi kecemasan sosial. Gretarsdottir, Woodruff-Borden, Meeks, dan Depp (2004) menemukan bahwa kelompok usia dewasa memiliki emosi negatif yang lebih rendah dari pada kelompok usia muda. Kecemasan sosial seringkali dijumpai pada masa remaja usia 15-29 tahun (Duran \& Barlow, 2006).

Menurut penelitian Spurr dan Stopa (2003), berdasarkan observasi, individu yang memiliki kecemasan sosial menghasilkan pikiran negatif lebih sering, berperilaku mencari aman, dan evaluasi diri yang negatif dalam kelompok. Penelitian Cartwright-Hatton, Tschernitz, dan Gomersall (2003) menunjukkan bahwa kecemasan sosial pada anak tidak hanya ditunjukkan oleh perilaku sosialnya, namun mereka juga memiliki kepercayaan bahwa mereka akan gugup selama berinteraksi. Penelitian Christensen, Stein, dan Christensen (2003) menyatakan bahwa seseorang dengan kecemasan sosial memandang negatif terhadap dirinya dan percaya bahwa orang lain juga memandang negatif terhadap dirinya.

Salah satu intervensi yang terbukti efektif menangani kecemasan ialah terapi kognitif perilaku atau cognitive behavioral therapy (CBT). Cooper dan Duffy (Tsiros dkk., 2008) menyebutkan bahwa terapi perilaku kognitif (CBT) adalah terapi psikologis didasarkan pada teori bahwa masalah tersebut dipertahankan oleh disfungsional kognisi dan keyakinan tertentu. Roth dan Heimberg (2002) berpendapat bahwa pendekatan CBT ini mengintegrasikan kognitif, perilaku, dan perubahan aspek sosial melalui proses belajar dan memproses informasi. 
Menurut Dattilo (Correy, 2005), Cognitive Behavior Therapy (CBT) dapat juga disebut terapi kognitif perilaku sebagaimana yang dikembangkan oleh Donald Meichenbaum, yaitu mengkombinasikan prinsip kognitif dan behavioral (perilakuan) dengan metode pendekatan yang singkat. Terapinya mengarahkan klien untuk memodifikasi fungsi berpikir, merasa dan bertindak, dengan menekankan peran otak dalam menganalisa. Jika klien mampu mengubah status pikiran dan perasaannya, klien diharapkan dapat mengubah tingkah lakunya dari negatif menjadi positif.

Roth dkk (2002) menyatakan bahwa terapi kognitif perilaku dapat digunakan dalam terapi individual dan kelompok, juga dapat digunakan untuk anak-anak, remaja, dan dewasa dengan berbagai budaya dan latar belakang.Terapi kognitif perilaku juga merupakan tritmen yang cukup efisien, untuk kasus kecemasan dan depresi yang ringan memerlukan waktu empat sampai 14 sesi.

Intervensi dalam menangani kecemasan sosial berdasarkan penelitian metanalisis Rodebaugh, Holaway, dan Heimberg (2004) terapi psikososial untuk kecemasan sosial adalah CBT. CBT memberikan efek positif pada kasus dewasa. Selain itu, CBT menunjukkan efektivitas untuk anak dan remaja. Efektivitas Terapi Kognitif Perilaku dalam Kelompok (CBT in Group) dalam menangani kecemasan sosial dilihat dari penelitian Wong dan Sun (2006) yang menyatakan bahwa Terapi Kognitif Perilaku dalam Kelompok efektif dalam mengurangi kecemasan sosial pada masyarakat Hongkong dengan peningkatan pada aspek pemecahan masalah dan emosi positif. Penelitian ini dilakukan selama 10 sesi tanpa menggunakan kelompok kontrol. Penelitian lain menggunakan Terapi Kognitif Perilaku dalam Kelompok dalam melihat kecemasan sosial adalah Hope, Burns, Hayes, Herbert, dan Warner (2007) melihat automatic thought dan konstruksi kognitif dalam Terapi Kognitif Perilaku dalam Kelompok pada gangguan kecemasan sosial.

Setiap penelitian CBT menerapkan jumlah sesi yang berbeda-beda. Penelitian Hirsch, Jolley, dan Williams (2000) mengenai evaluasi pelaksanaan CBT pada 52 kasus depresi, 42 kecemasan, dan empat kasus campuran antara depresi dan kecemasan, menunjukkan bahwa CBT dapat dilakukan dalam 4-18 sesi kurang lebih 2-12 bulan dengan setiap sesi berlangsung selama satu jam. Namun pada pelaksanaannya juga fleksibel tergantung dari masalahnya. Selain itu, terapi dalam kelompok memungkinkan klien merasa memperoleh dukungan dan motivasi, berkurang pikiran negatif tentang tubuh, berkurang kesalahan kognitif dalam mengevaluasi penampilan mereka, dan berkurang kecemasan menjadi gemuk. Lebih lanjut, terapi ini juga meningkatkan harga diri dan mengurangi kecemasan sosial, dan beberapa gejala depresi 
(McLean, dkk., 2011; Chen, dkk., 2003; Faucher, 2008)

Tujuan dari terapi ini adalah rekonstruksi kognitif untuk mengubah pikiranpikiran negatif dan sistem kepercayaan yang salah. Hipotesis penelitian ini adalah terdapat perbedaan penurunan kecemasan sosial pada remaja putri dengan obesitas setelah diberikan cognitive behavioral therapy in group pada kelompok eksperimen dibandingkan kelompok kontrol.

\section{METODE PENELITIAN}

\section{Subjek Penelitian}

Subjek dalam penelitian ini adalah Remaja Putri SMA Yogyakarta yang memiliki IMT minimal 25. Usia remaja antara 12-18 tahun, memiliki kecemasan sosial pada tingkat sedang sampai tinggi sesuai hasil diary checklist kecemasan sosial yang yang disusun berdasarkan aspek yang dikemukakan oleh Nevid (2003). Subjek yang terlibat dalam program ini berjumlah 5 orang kelompok eksperimen serta 5 orang kelompok kontrol. Subjek tidak memiliki penyakit kronis. Seleksi partisipan dilakukan bekerjasama dengan pihak sekolah berdasarkan kriteria, yaitu siswa yang mengalami kelebihan berat badan atau kegemukan dan kecemasan social sedang dan tinggi.

\section{Rancangan Penelitian}

Rancangan pada penelitian ini dilakukan dalam bentuk eksperimen terhadap dua kelompok, yaitu kelompok eksperimen dan kelompok kontrol. Kelompok eksperimen merupakan kelompok yang akan diberikan terapi, sedangkan kelompok kontrol merupakan kelompok yang tidak diberikan terapi. Penelitian ini menggunakan desain eksperimen the untreated control group design with dependent pre-test and posttest samples (Shadish, Cook, \& Campbell, 2005).

Tabel 2. Rancangan Pengukuran Eksperimen

\begin{tabular}{ccccc}
\hline Kelompok & Prates & Terapi & Pascates & Tindak lanjut \\
\hline Ekperimen & O1 & $X$ & O2 & O3 \\
Kontrol & O1 & - & O2 & O3 \\
\hline
\end{tabular}

Keterangan:

O1 : pengukuran sebelum dilakukan intervensi (Prates)

O2 : pengukuran setelah diberikan intervensi (Pascates)

O3 : pengukuran 2 minggu setelah di-berikan intervensi (Tindak lanjut)

$X \quad$ : intervensi Terapi Kognitif Perilaku dalam Kelompok 


\section{Metode Pengumpulan Data}

Pengumpulan data pada penelitian ini dilakukan suatu pengukuran sebanyak tiga kali dengan menggunakan alat ukur diary checklist kecemasan sosial, terhadap kelompok eksperimen. Pengukuran pertama dilakukan tiga hari sebelum terapi (prates), pengukuran kedua dilakukan saat terapi selesai diberikan (pascates), dan pengukuran ketiga dilakukan dua minggu setelah terapi diberikan (follow-up). Pada kelompok kontrol juga dilakukan pengukuran sebanyak tiga kali di waktu yang bersamaan, namun tidak diberikan terapi.

\section{Prosedur Intervensi}

Instrumen Penelitian. Instrumen yang digunakan dalam penelitian ini:

1. Modul dan Materi terapi bagi Terapis

2. Penggunaan diary checklist kecemasan sosial sebagai alat ukur

3. Surat persetujuan (informed consent) untuk subjek dan orangtua subjek

4. Lembaran evaluasi program terapi

5. Lembaran observasi peserta terapi

6. Lembar kerja subjek
Persiapan Intervensi. Persiapan intervensi penelitian meliputi:

1. Asesmen awal untuk menganalisis kebutuhan di lapangan.

2. Menentukan partisipan

3. Menyusun diary checklist kecemasan sosial

4. Uji coba diary checklist kecemasan sosial

5. Menyusun modul panduan Terapi Kognitif Perilaku dalam Kelompok

6. Uji coba modul

7. Mengisi lembar persetujuan atau informed consent

Pelaksanaan Intervensi. Terapi di-lakukan oleh Psikolog Klinis yang telah berpengalaman. Dalam penelitian ini terapi dilakukan oleh Psikolog Puskesmas yang bekerjasama dengan peneliti dalam menjalankan penelitian ini. Subjek diberikan Terapi Kognitif Perilaku dalam Kelompok. Penelitian ini dilakukan selama tujuh kali per temuan, seminggu dua kali, dengan masing-masing pertemuan berlangsung kurang lebih 90 hingga 120 menit.

Tabel 3. Kegiatan Terapi Kognitif Perilaku dalam Kelompok:

\begin{tabular}{cl}
\hline Pertemuan & \multicolumn{1}{c}{ Kegiatan } \\
\hline 1 & Pembukaan Terapi dan pembentukan goal setting \\
2 & Thought Catching (Penangkapan Pikiran) \\
3 & Thought Catching (Penangkapan Pikiran) dan \\
& Testing Realitas (Pengujian kondisi yang sebenarnya) \\
4 & Testing Realitas (Pengujian kondisi yang sebenarnya) \\
5 & Graduated Exposure \\
7 & Graduated Exposure \\
\hline
\end{tabular}




\section{Metode Analisis Data}

Analisis data dilakukan secara kuantitaif dan kualitatif. Analisis kuantitatif dilakukan dengan uji Wilcoxon antara hasil prates, pascates dan tindak lanjut pada kelompok eksperimen dan kelompok kontrol menggunakan SPSS for windows.

\section{HASIL PENELITIAN}

\section{Deskripsi Data}

Penelitian melibatkan satu kelompok eksperimen dan satu kelompok kontrol. Kelompok eksperimen berjumlah lima orang dari tujuh orang yang direncanakan. Kelompok kontrol berjumlah lima orang. Subjek yang gugur dikarenakan tidak mengikuti seluruh proses intervensi. Pengukuran dilakukan sebanyak tiga kali, yaitu sebelum perlakukan (prates), segera setelah perlakuan (pascates) dan satu minggu setelah perlakuan (tindak lanjut atau follow-up).

Berdasarkan hasil analisis deskriptif dapat dilihat bahwa terjadi penurunan ranking prates dan pascates pada kelompok eksperimen. Pada kelompok kontrol ranking prates dan pascates cenderung tidak mengalami perubahan yang signifikan. Ranking pascates dan tindak lanjut juga cenderung tidak mengalami perubahan yang signifikan, baik pada kelompok kontrol dan kelompok eksperimen. Hal ini menunjukkan bahwa terjadi penurunan kecemasan sosial pada kelompok eksperimen setelah diberikan intervensi Terapi Kognitif Perilaku dalam Kelompok, berbeda dengan kelompok kontrol yang tidak mengalami perubahan kecemasan sosial.

Tabel 4. Deskripsi Data Hasil Penelitian

\begin{tabular}{lcccccc}
\hline \multicolumn{1}{l}{ Kelompok Eksperimen } & & \multicolumn{4}{c}{ Kelompok Kontrol } \\
\hline Ranking & SD & Min & Max & SD & Min & Max \\
Prates & 8,422 & 21 & 41,33 & 6,259 & 20 & 36,33 \\
Pascates & 2,274 & 17 & 22,67 & 5,800 & 21 & 36,00 \\
Tindak lanjut & 1,545 & 17 & 20,00 & 6,768 & 20 & 38,33 \\
\hline
\end{tabular}

Berikut ini adalah data perbandingan berdasarkan rerata Diary Kecemasan hasil ketiga pengukuran pada kelompok sosial selama tiga hari: eksperimen dan kelompok kontrol 


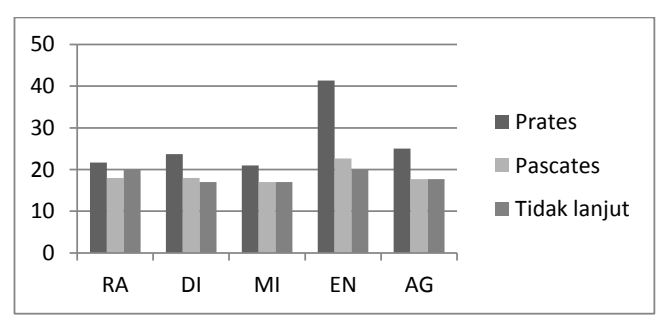

Gambar 1. Histogram perbandingan pengukuran kecemasan sosial pada kelompok eksperimen

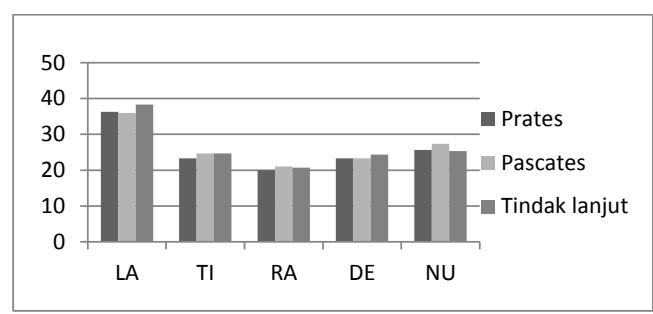

Gambar 2. Histogram perbandingan pengukuran kecemasan sosial pada kelompok kontrol

\section{Hasil Uji Hipotesis}

Uji Wilcoxon dilakukan untuk melihat arah perubahan ranking sebelum dan sesudah diberikan perlakuan.

Tabel 5. Ringkasan Uji Wilcoxon Prates dan Pascates Kecemasan Sosial

\begin{tabular}{|c|c|c|c|c|c|c|}
\hline \multirow{2}{*}{ Kelompok } & \multicolumn{2}{|c|}{ Rerata Ranking } & \multirow{2}{*}{$\begin{array}{c}\text { Perubahan } \\
\text { Ranking }\end{array}$} & \multirow{2}{*}{$\mathbf{Z}$} & \multirow{2}{*}{$\begin{array}{l}\text { Signifikansi } \\
\text { (p) }\end{array}$} & \multirow{2}{*}{ Keputusan } \\
\hline & Prates & Pascates & & & & \\
\hline KE & 26,5340 & 18,6680 & $-15,00$ & $-2,023$ & $\begin{array}{c}0,043 \\
(p<0,05)\end{array}$ & Signifikan \\
\hline KK & 25,7320 & 26,4660 & $+9,00$ & $-1,461$ & $\begin{array}{c}0,144 \\
(p>0,05)\end{array}$ & $\begin{array}{c}\text { Tidak } \\
\text { signifikan }\end{array}$ \\
\hline
\end{tabular}

Berdasarkan tabel dapat dilihat rerata ranking pada kelompok eksperimen mengalami penurunan ranking prates dan pascates setelah diberikan intervensi. Hal ini didukung oleh perubahan ranking yang negatif dan nilai $Z=-2,023(p=0,043$; $p<0,05)$. Hal ini menunjukkan terjadi penurunan kecemasan sosial yang signifikan pada pengukuran prates dan pascates kelompok eksperimen setelah diberikan perlakuan. Pada data kelompok kontrol mengalami kenaikan ranking kecemasan sosial kelompok kontrol menunjukkan hasil yang tidak signifikan, dengan nilai $Z=-1,461 \quad(p=0,144$; $p>0,05)$, sehingga dapat dinyatakan tidak terdapat penurunan kecemasan sosial yang tidak signifikan pada kelompok kontrol. 
Tabel 6. Ringkasan Uji Wilcoxon Pascates dan Tindak lanjut Kecemasan Sosial

\begin{tabular}{|c|c|c|c|c|c|c|}
\hline \multirow[b]{2}{*}{ Kelompok } & \multicolumn{2}{|c|}{ Rerata Ranking } & \multirow{2}{*}{$\begin{array}{c}\text { Perubahan } \\
\text { Ranking }\end{array}$} & \multirow[b]{2}{*}{$\mathbf{Z}$} & \multirow{2}{*}{$\begin{array}{l}\text { Signifikansi } \\
\text { (p) }\end{array}$} & \multirow[b]{2}{*}{ Keputusan } \\
\hline & Pascates & $\begin{array}{l}\text { Tindak } \\
\text { lanjut }\end{array}$ & & & & \\
\hline KE & 18,6680 & 18,3340 & $-4,00$ & $-0,535$ & $\begin{array}{c}0,593 \\
(p>0,05)\end{array}$ & $\begin{array}{c}\text { Tidak } \\
\text { signifikan }\end{array}$ \\
\hline KK & 26,4660 & 26,6660 & $+6,00$ & $-0,365$ & $\begin{array}{c}0,715 \\
(p>0,05)\end{array}$ & $\begin{array}{c}\text { Tidak } \\
\text { signifikan }\end{array}$ \\
\hline
\end{tabular}

Hasil pascates dan tindak lanjut pada kelompok eksperimen menunjukkan adanya penurunan kecemasan sosial yang tidak signifikan pada kelompok eksperimen, yang dilihat dari nilai $Z=$ $-0,535(p=0,593 ; p>0,05)$. Kelompok kontrol menunjukkan tidak adanya penurunan kecemasan sosial yang tidak signifikan, yang dilihat dari nilai $\mathrm{Z}=$ $-0,365(p=0,715 ; p>0,05)$

Berdasarkan uraian hasil analisis kuantitatif dapat disimpulkan bahwa hipotesis dalam penelitian ini diterima, yaitu terdapat perbedaan penurunan kecemasan sosial pada remaja putri dengan obesitas setelah diberikan terapi kognitif perilaku dalam kelompok pada kelompok eksperimen dibandingkan kelompok kontrol.

\section{PEMBAHASAN}

Hasil penelitian menunjukkan terdapat perbedaan kecemasan sosial pada kelompok eksperimen dan kelompok kontrol sebelum dan sesudah perlakuan. Terdapat penurunan ranking kecemasan sosial pada kelompok eksperimen yang diberikan Terapi Kognitif Perilaku dalam Kelompok dibandingkan kelompok kontrol.

Hasil penelitian ini sekaligus memperkuat hasil dari penelitian-penelitian yang telah dilakukan sebelumnya. Wong dan Sun (2006) menunjukkan hasil penelitian yang menyatakan bahwa Terapi Kognitif Perilaku dalam Kelompok efektif dalam mengurangi kecemasan sosial pada masyarakat Hongkong dengan peningkatan pada aspek pemecahan masalah dan emosi positif. Berdasarkan penelitian metanalisis Rodebaugh, Holaway, dan Heimberg (2004), diketahui bahwa terapi psikososial untuk kecemasan sosial adalah CBT.

Penampilan fisik merupakan hal yang sangat penting bagi remaja putri karena pada masa ini individu mulai banyak berinteraksi (Citra \& Retnaningsih, 2009). Dalam dunia sosial kecantikan dan ketertarikan merupakan hal yang membuat remaja menjadi nyaman. Apabila ada bagian tubuh atau seluruh tubuh yang dinilai tidak baik atau tidak 
sesuai dengan gambaran tubuh ideal oleh remaja, maka remaja cenderung akan mengalami hambatan dalam proses sosialisasinya (Monks dkk., 2003). Menurut Astuti (2005), remaja putri yang mengalami obesitas ternyata memiliki kecenderungan mengalami hambatan dalam melakukan penyesuaian sosial. Dalam situasi sosial, penderita obesitas yang mengalami kecemasan sosial memonitor situasi yang mengancam, seperti celaan maupun penolakan dan selalu merasa diawasi oleh orang lain, sehingga berusaha menghindari situasi sosial yang lebih jauh (Avants, Margolin, Kosten, \& Rounsaville, 1998). Hal inilah yang dapat membuat remaja putri dengan obesitas mengalami social anxiety yang selanjutnya akan disebut sebagai kecemasan sosial.

Kecemasan sosial memiliki beberapa karakteristik, yaitu kognitif yang negatif dalam mengevaluasi dirinya dan lingkungannya, perilaku bentuk penolakan terhadap lingkungan serta menarik diri, dan manifestasi fisik berupa jantung berdebar, bicara terbata-bata, dan sebagainya (Nevid,dkk, 2003). CBT menggunakan teknik terapi perilaku dalam upaya untukmemodifikasi perilaku dengan mengubah anteseden dan konsekuensi serta menggabungkan keduanya dengan teknik kognitif yang dirancang untuk mengidentifikasi, mengevaluasi dan kemudian merestrukturisasi kognisi dan disfungsional keyakinan. CBT juga menggunakan strategi untuk mengem- bangkan penerapan keahlian baru dan perilakuyangdipelajari saatterapi kedalam kehidupan sehari-hari dan pemeliharaan perubahan sepanjang waktu (Cooper, dkk, Butler, dkk dalam Tsiros, 2008). Terapi Kognitif Perilaku dalam Kelompok memodifikasi fungsi berpikir, merasa dan bertindak, dengan menekankan peran otak dalam menganalisis. Jika peserta mampu mengubah status pikiran dan perasaannya, peserta dapat mengubah tingkah lakunya dari negatif menjadi positif.

Hal ini didukung oleh hasil analisis kualitatif ada sedikit perubahan tingkat kecemasan subjek penelitian (Ra) saat dipanggil guru sebelum dan sesudah ia mengikuti proses terapi, setelah mengikuti proses terapi Ra mencoba untuk tidak begitu mengkhawatirkan apa yang akan orang pikirkan jika ia berjalan di depan umum saat di panggil guru. Hal ini juga terjadi pada Mi yang mulai mencoba untuk bergabung dengan teman-teman yang lebih kecil darinya. Selain itu jika ada teman yang membicarakan mengenai tubuh Mi tidak berfikiran akan diejek, dan mulai mengatasi rasa cemasnya ketika maju ke depan kelas. Selain itu Ag mengalami perkembangan dengan berpikir bahwa jika ia berjalan dengan kakaknya orang-orang bukan membandingkan tubuhnya namun melihat wajahnya yang cantik. Selain itu jika ia merasa malu untuk memulai percapakan dengan orang lain. Hal ini mendukung hasil analisis kuantitatif 
yang menunjukkan terdapat penurunan ranking kecemasan sosial pada kelompok eksperimen yang diberikan Terapi Kognitif Perilaku dalam Kelompok dibandingkan kelompok kontrol.

Pelaksanaan Terapi Kognitif Perilaku dalam Kelompok dilakukan dalam kelompok agar para peserta dapat saling berbagi dan mengkomunikasikan perasaannya kepada peserta lain yang mengalami hal yang sama sehingga mereka dapat saling belajar, saling menerima, dan saling memberi dukungan. Menurut penelitian Grant dan Cash (Faucher, 1995), klien yang mengalami ketidakpuasan tubuh dapat meraih keberhasilan yang cukup baik melalui terapi CBT kelompok dibanding mengikuti terapi CBT secara individu.

Selain itu, penelitian lain dari Hope, Burns, Hayes, Herbert, dan Warner (2007) juga menunjukkan hasil serupa mengenai Terapi Kognitif Perilaku dalam Kelompok dalam menangani kecemasan sosial. Hasil penelitian tersebut menyatakan bahwa Terapi Kognitif Perilaku dalam Kelompok dapat menangani kecemasan sosial dengan melihat tiga tema utama automatic thought yang tergambar, yaitu mengalami kecemasan, evaluasi diri yang negatif, dan ketakutan pada orang lain mengevaluasi negatif.

Masa remaja awal merupakan peralihan kebergantungan dari keluarga menuju ke teman sebaya sehingga penerimaan teman sebaya merupakan fokus utama pada remaja (Steinberg, 2002). Monks, Knoers, dan Haditono (1998) menjelaskan bahwa remaja mempunyai perhatian yang sangat besar terhadap penampilan dirinya. Apabila ada bagian tubuh atau seluruh tubuh yang dinilai tidak baik atau tidak sesuai dengan gambaran tubuh ideal oleh remaja, maka cenderung akan mempunyai proses sosialisasi remaja (Monks dkk., 1998). Pada lingkungan yang menghargai badan kurus, remaja dengan berat badan berlebih seringkali secara subjektif dibedakan, diejek, dan menjadi korban (Stang, 2005).

Penerimaan teman sebaya ini kurang didapat oleh remaja dengan obesitas. Mereka mendapat stigma negatif dan tekanan untuk mengurangi berat badan teman sebaya supaya mendapat penerimaan dari kelompok (Thompson \& Smolak dalam Verplanken \& Velsvik, 2008). Hal ini sesuai dengan kondisi partisipan yang mendapat ejekan dari teman, merasa dan mengalami kecemasan tidak memiliki teman. Terapi kelompok menyediakan penerimaan, dukungan, dan kepercayaan sehingga anggota dapat memperlihatkan lebih banyak emosi dan pikiran pribadi dan mengetahui bahwa anggota kelompok akan memahami dan empati (Yalom dalam Bieling, Mc.Cabe, \& Anthony, 2006).

Terapi kelompok efektif diterapkan pada gangguan yang melibatkan penilaian sosial (Heimberg dalam Bieling, Mc.Cabe, \& Anthony, 2006). Dalam kelompok, 
partisipan memiliki kesempatan lebih besar untuk dapat menyadari kesalahan berpikir yang dimiliki oleh orang lain dari pada kesalahannya berpikirnya sendiri (Heimberg dalam Bieling, Mc.Cabe, \& Anthony, 2006). Terapi kelompok memungkinkan partisipan menguji pikiran dan perasaan melalui perspektif anggota lain, dan mendapatkan feedback dari teman sebaya (Andersen, 2008).

Kelemahan dalam penelitian ini adalah tidak ada kontrol pada faktor eksternal yang dimungkinkan juga dapat menurunkan kecemasan sosial di luar pemberian Terapi Kognitif Perilaku dalam Kelompok. Peneliti seharusnya langsung memilih sendiri subjek penelitian dengan melakukan screening murid satu persatu, bukan guru sekolah yang memilih subjek yang kemungkinan hanya dengan melihat obesitas dari fisik nya. Hasil penelitian tidak dapat menunjukkan seberapa besar Terapi Kognitif Perilaku dalam Kelompok mampu menurunkan kecemasan sosial. Hal ini dikarenakan penelitian ini hanya melihat penurunan ranking saja. Pengukuran dengan pengisian diary checklist kecemasan sosial yang membutuhkan waktu selama tiga hari menimbulkan keterbatasan pengungkapan nilai kecemasan sosial karena dipengaruhi oleh aktifitas hari yang berbeda-beda.

Kendala dalam penelitian adalah sulitnya memperoleh peserta yang sesuai dengan kriteria yang sudah ditentukan oleh peneliti dan bersedia mengikuti proses terapi. Hasil penelitian ini juga belum dapat digeneralisasi pada populasi yang lebih besar karena situasi dan karakteristik subjek yang sangat spesifik serta jumlah subjek yang sangat sedikit.

\section{SIMPULAN DAN SARAN}

\section{Simpulan}

Berdasarkan uraian analisis di atas, dapat disimpulkan bahwa terdapat perbedaan penurunan kecemasan sosial pada remaja putri dengan obesitas setelah diberikan cognitive behavioral therapy in group pada kelompok eksperimen dibandingkan kelompok kontrol. Program Terapi Kognitif Perilaku dalam Kelompok ini dilakukan sebanyak tujuh kali pertemuan yang dilakukan seminggu dua kali dengan jeda pertemuan dua sampai tiga hari dan durasi 90-120 menit pada masing-masing pertemuan.

\section{Saran}

Adapun saran pada penelitian selanjutnya diharapkan melakukan kontrol terhadap faktor eksternal yang juga mampu menurunkan kecemasan sosial pada remaja dengan obesitas, sehingga saat terjadi penurunan ranking kecemasan sosial pada remaja putri itu dikarenakan proses Terapi Kognitif Perilaku dalam Kelompok yang dilakukan. Selain itu untuk penelitian selanjutnya dapat menambah jumlah kelompok Terapi Kognitif Perilaku dalam Kelompok sesuai dengan aturan statistik parametrik. Hal ini dilakukan supaya 
hasil penelitian dapat digeneralisasi lebih luas dan dapat menganalisis kovarian dari variabel dependen. Sebaiknya peneliti mengontrol peserta dalam pengisian diary checklist kecemasan sosial yang membutuhkan waktu selama tiga hari. Hal ini dikarenakan pengukuran kecemasan sosial yang dilakukan selama tiga hari tanpa pengontrolan menyebabkan peristiwa yang terjadi belum dapat terwakili sepenuhnya karena dipengaruhi oleh aktifitas hari yang berbeda-beda.

\section{DAFTAR PUSTAKA}

Andersen, J. (2008). The Body Therapy. Dalam Brook, S.L., The Creative Therapies and Eating Disorders. Illinois: Charles Thomas Publishers.

Astuti, N.L. (2005). Obesitas \& Penyesuaian Sosialnya. Laporan Praktek Kerja Lapangan Bidang Psikologi Sosial. (Tidak diterbitkan). Yogyakarta: Fakultas Psikologi UGM.

Avants, S.K., Margolin, A., Kosten, T.R., Rounsaville, B.J., \& Schottenfeld, R.S. (1998). When is Loss Treatment Better? The Role of Social anxiety in Matching Methadone Patients to Psychosocial Treatments. Journal of Consulting and Clinical Psychology, 66, 924-931.

Barlow. D.H \& Duran.V.M. (2006). Intisari Psikologi Abnormal Edisi ke Empat. Yogyakarta: Pustaka Pelajar
Bieling, P.J., McCabe, R.E., Antony, M.M. (2006). Cognitive Behavioral Therapy in Groups. New York: The Guilford Press.

Blumenthal, H., Leen-Feldner, E.W., Babson, K.A., Gahr, J.L., Trainor, C.D., \& Frala, J.L. (2011). Elevated social anxiety among early maturing girls. Journal Developmental Psychology, 47, 1133-1140. doi:10.1037/ a0024008.

Cartwright-Hatton. S., Tschernitz.N., \& Gomersall. H. (2003). Social Anxiety in Children: Social Skills Deficit or Cognitive Distortion? Behaviour Research and Therapy, 20, 1-11. doi:10.1016/j.brat.2003.12.003.

Chen, E., Touyz, S.W., Beumont, P.J.V., Fairburn, C.G., Griffiths, R., Butow, P., Russell, J., Schotte, D.E., Gertler, R., Basten, C. (2003). Comparison of Group and Individual CognitiveBehavioral Therapy for Patients with Bulimia Nervosa. Eating Disorders Research Society, 241-254. doi: 10.1002/et.10137.

Christensen, P.N., Stein, M.B., \& Christensen, A.M. (2003). Social Anxiety and Interpersonal Perception: A Social Relations Model Analysis. Behaviour Research and Therapy, 41, 1355-1371. doi:10.1016/ S0005-7967(03)00064-0. 
Citra, A.F., \& Retnaningsih. (2009). Konsep Diri Remaja Awal Putri Yang Mengalami Obesitas. Jurnal Psikologi, 2 (2), 166-171.

Correy, G. (2005). Theory and Practice of Counseling and Psychoterapy ( $7^{\text {th }}$ edition). USA: Brooks/Cole.

Faucher, C. (2008). Cognitive Behavior Therapy as a Treatment for Body Image Dissatisfaction.http://www. vanderbilt.edu/ans/psychology/ health_psychology/BI_Therapy.htm. Diakses pada tanggal 23 Januari 2012.

Gretarsdottir, E., Woodruff_Borden, J., Meeks, S., \&Depp, C.A. (2004). Social anxiety in Older Adults: Phenomenology, Prevalence, and Measurement. Journal Behaviour Research and Therapy, 42, 459-475.doi:10.1016/ S0005-7967(03)00156-6.

Hirsch, C., Jolley, S., \& Williams, R. (2000). A Study of Outcome in a Clinical Psychology Service and Preliminary Evaluation of Cognitive Behavioral Therapy in Real Practice. Journal of Mental Health, 9 (5), 537-549.

Hoffman, L., Paris, S., \& Hall, E. (1994). Develpomental Psychology Today (6 ${ }^{\text {th }}$ edition). New York: McGrawHill.Inc.
Hope, D.A., Burns, J.A., Hayes, S.A., Herbert, J.D., \&Warner, M.D. (2007). Automatic Thoughts and Cognitive Restructuring in Cognitive Behavioral Group Therapy for Social Anxiety Disorder. Cognitive Therapy, 34, 1-12.doi:10.1007/ s10608-007-9147-9.

Mc.Lean, S.A., Paxton, S.J. \& Wertheim, E.H. (2011). A Body Image and Disordered Eating Intervention for Women in Mildlife: A Randomized Controlled Trial. Journal of Consulting and Clinical Psychology, 79 (6), 751-758. doi: 10. 1037/a0026094.

Monks, F.J., Knoers, A.M.P., \& Haditono, S. R. (2003). Psikologi Perkembangan. Yogyakarta: Gadjah Mada University Press.

Nevid, J.S., Rathus, S.A., \& Greene, B. (2003). Psikologi Abnormal (Edisi kelima, Jilid 1). Jakarta: Erlangga.

Rikesdas. (2007). Laporan Hasil Riset Kesehatan Dasar. Tanggal akses dan unduh 24 Januari 2012. http://www. docstoc.com/docs/19707850/Laporan-Hasil-Riset-Kesehatan-Dasar(RISKESDAS)-Nasional-2007.html.

Rodebaugh, L.T., Holaway, R.M., \& Heimberg, R.G. (2004). The Treatment of Social Anxiety Disorder. Journal Clinical Psychology Review, 24, 883-908.doi:10.1016/j. cpr.2004.07.007. 
Roth, D.A., Eng, W., \& Heimberg, R.G. (2002). Cognitive Behavior Therapy. Encyclopedia of Psychoterapy, 1, 451-458.

Sarafino, E.P. (1998). Health Psychology: Biopsychosocial Interaction ( $3^{\text {rd }}$ edition). New York: John Wiley and Sons.Inc.

Santrock, J.W. (2003). Adolescene Perkembangan Remaja. Jakarta: Erlangga.

Shadish, W,R., Cook, T,D., \& Campbell, D, T. (2002). Experimental and Quasi-Experimental Design For Generalized Causal Inference. New Yorks. Houghton Mifflin Company.

Spurr, J.M., \& Stopa, L. (2003). The Observer Perspective: Effects on Social Anxiety and Performance. Journal Behaviour Research And Therapy, 41, 1009-1028.doi:10.1016/ S0005-7967(02)00177-8.

Stang J., \&Story M (eds). (2005). Guidelines for Adolescent Nutrition Services. http://www.epi.umn.edu/let/ pubs/adol_book.shtm. Diakses pada tanggal 23 Januari 2012.

Steinberg, L.D. (2002). Adolescence Sixth Edition. New York: McGraw-Hill.
Sukamto, M.E. 2005. Efektivitas Bibliotherapy dalam Mengurangi Ketidakpuasan Terhadap Citra Tubuh (Body Image Dissatisfacction) Pada Sisswi SMU. Tesis (tidak diterbitkan). Program Pascasarjana Fakultas Psikologi Universitas Gadjah Mada Yogyakarta.

Tsiros, M.D., Sinn, N., Brennan, L., Coates, A.M., Wakley, J.W., Petkov, J., Howe, P.R.C., \& Buckley, J.D. (2008). Cognitive Behavioral Therapy Improves Diet And Body Composition In Overweight And Obese Adolescents. American Society for Nutrition, 87, 1134-1140.

Verplanken, B. \& Velsvik, R. (2008). Habitual Negative Body Image Thinking as Psychological Risk Factor in Adolescents. Body Image, 5, 133-140, doi:10.1016/j.bodyim.2007.11.001.

Wong, D.F.K., \&Sun, S.Y.K. (2006). A Preliminary Study of the Efficacy Of Group Cognitive-Behavioral Therapy For People With Social Anxiety in Hongkong. Hongkong J Psychiatry, 16, 50-56. 